\title{
Sulphinpyrazone and the platelet serotoninergic mechanism in ischaemic heart disease
}

\author{
V K PURI, A RAWAT, A SHARMA, A MEHROTRA, M HASAN, K SHANKER, \\ $M$ VERMA, J N SINHA, K P BHARGAVA
}

\begin{abstract}
A double blind study in 25 patients with ischaemic heart disease and 20 matched healthy controls examined the effect of sulphinpyrazone on the uptake of serotonin by platelets and the basal concentrations of serotonin in platelets. Uptake was measured using tritium labelled serotonin and basal concentrations estimated spectrophotofluorometrically. Serotonin uptake was significantly increased both in the patients with chronic stable angina of effort and in those with a history of myocardial infarction six months or more previously. Sulphinpyrazone reduced serotonin uptake from $\mathbf{9 4 . 2 5}$ (SE 8.65) to $57.86(5 \cdot 37$ ) $\mathrm{cpm} / 10^{8}$ platelets after 24 weeks of treatment in the group with stable angina and from $137.45(16.26)$ to $68.08(8.38) \mathrm{cpm} / 10^{8}$ platelets in the myocardial infarction group. Raised basal concentrations in the two groups were also reduced by sulphinpyrazone. Placebo had no effect on serotonin uptake or basal concentrations in either group of patients.

The ability of sulphinpyrazone to inhibit uptake and reduce basal concentrations of serotonin in patients with ischaemic heart disease may be yet another mechanism through which this drug exerts its beneficial antiplatelet effect.
\end{abstract}

\section{Introduction}

The results of the Anturane (sulphinpyrazone) reinfarction trial showed the beneficial effects of this drug in preventing sudden death after myocardial infarction, though its exact mechanism of action was not clear. ' 2 Various antiplatelet agents act in different ways-for example, sulphinpyrazone and aspirin inhibit the platelet arachidonic pathway and therefore the synthesis of thromboxane $A_{2}$ and platelet aggregation, ${ }^{3}$ whereas dipyridamole increases platelet cyclic adenosine monophosphate concentrations, thus inhibiting platelet calcium activation, leading to inhibition of platelet aggregation and adhesion.

Other mechanisms through which sulphinpyrazone may act are by reducing thrombus formation ${ }^{4}$ and preventing ultrastructural changes in platelet morphology.' In addition, in vitro studies show that sulphinpyrazone inhibits the release of serotonin by platelets, ${ }^{6}$ affects platelet survival time, ${ }^{7}$ and reduces platelet aggregation. ${ }^{\times}$

Platelets are the main reservoir of serotonin in man and show definite uptake and efflux of this amine. ${ }^{4}$ We have reported finding a significant increase in serotonin uptake by platelets from patients

Department of Cardiology, King George's Medical College, Lucknow 226003, India

V K PURI, DM, MRCP, reader

A RAWAT, MD, research associate

A SHARMA, MD, research associate

A MEHROTRA, MD, pool officer

M HASAN, MD, FRCP, professor and head of department

Department of Pharmacology, King George's Medical College, Lucknow K SHANKER, MSC, PHD, pharmaceutical chemist

$M$ VERMA, PHD, research associate

J N SINHA, $M D$, reader

K P BHARGAVA, MD, PHD, professor and head of department

Correspondence to: Dr V K Puri, Department of Cardiology, Queen Elizabeth Hospital, Edgbaston, Birmingham B15 2TH. with ischaemic heart disease, ${ }^{10}$ and the present study examines the effect of sulphinpyrazone on this mechanism.

\section{Subjects and methods}

Twenty five patients with ischaemic heart disease and 20 controls matched for age and sex (healthy volunteers) were selected for the study. The patients comprised 22 men and three women with a mean age of $50 \cdot 1$ years (range 33 60 ). Eleven were suffering from chronic stable angina of effort and 14 had effort angina as a legacy of myocardial infarction six months or more previously. In all cases myocardial infarction had been diagnosed according to established criteria. ${ }^{11}$ All patients and controls were subjected to a routine clinical check, electrocardiography, and a treadmill stress test. Ischaemic heart disease in the chronic stable angina group was established with the help of positive treadmill stress test findings according to Chung's criteria ${ }^{12}$ and by coronary angiography when indicated.

No subject had any history of depression or psychosis or had taken any antidepressant or neuroleptic drugs. Foods and drugs influencing biogenic amine metabolism were avoided from three days before the study.

After allowing the patients a washout period of two weeks during which all previous medications were stopped and only nitroglycerin permitted all subjects had initial estimations of their serotonin uptakes and basal concentrations in platelets. The patients were then given alternately and on a double blind basis either sulphinpyrazone ( $400 \mathrm{mg}$ twice daily) or identical looking capsules of placebo. Decoding was done at the end of the study.

Serotonin uptake was re-estimated in all subjects at 12 weekly intervals and basal concentrations re-estimated in the patients after 24 weeks of treatment. The entire study was conducted over one year. Statistical analysis was by Student's $t$ test (unpaired).

Collection of blood-Platelet rich plasma was prepared by the method of Born and Gilson. ${ }^{13}$ Glassware used in the experiments was coated with silicon. Blood samples were collected from cubital veins. Nine $\mathrm{ml}$ blood was immediately transferred into a centrifuge tube of cellulose acetate containing $1 \mathrm{ml}$ sodium citrate buffer $(3 \cdot 8 \% ; 129 \mathrm{mmol} / \mathrm{l})$ to give a final concentration of $12.9 \mathrm{mmol} / \mathrm{l}$ and placed in an ice bath. Blood was centrifuged at $200 \mathrm{~g}$ for 15 minutes at $0^{\circ} \mathrm{C}$. The supernatant platelet rich plasma was carefully taken out. Platelet counts were done in a Naebourhaemocytometer at a dilution of $1 / 20$.

Measurement of serotonin uptake by platelets-Serotonin uptake was measured by determining the concentration of radioactivity in platelets incubated with tritium labelled serotonin binoxalate (see below). Platelet rich plasma samples $(1 \mathrm{ml})$ were preincubated in duplicate for five minutes at

TABLE I-Mean (SE) platelet counts in patients with ischaemic heart disease and controls

\begin{tabular}{lccc}
\hline \multirow{2}{*}{ Group } & & \multicolumn{2}{c}{ Platelets $\left(\times 10^{8 / \mathrm{ml})}\right.$} \\
\cline { 3 - 4 } \cline { 3 - 4 } & No & Before sulphinpyrazone & After sulphinpyrazone \\
\hline Controls & 20 & $1.36(0.25)$ & - \\
Angina & 11 & $1.32(0.73)$ & $1.47(0.52)$ \\
Myocardial infarction & 14 & $1.56(0.32)$ & $1.38(0.36)$ \\
\hline
\end{tabular}

TABLE II-Mean (SE) serotonin uptake in patients with ischaemic heart disease and controls

\begin{tabular}{lcc}
\hline \multicolumn{1}{c}{ Group } & No & $\begin{array}{c}\text { Platelet serotonin uptake } \\
\text { (cpm/10* platelets) }\end{array}$ \\
\hline Controls & 20 & $28 \cdot 14(2 \cdot 76)$ \\
Angina & 11 & $89 \cdot 85(7 \cdot 68)^{\star}$ \\
Myocardial infarction & 14 & $141 \cdot 80(11 \cdot 41)^{\star \star}$ \\
\hline
\end{tabular}

Compared with control value: ${ }^{\star} p<0 \cdot 01 ;{ }^{\star \star} p<0 \cdot 001$ 
$37^{\circ} \mathrm{C}$. Serotonin was then added $(1 \mathrm{pmol} / \mathrm{ml} ; 25 \mu \mathrm{l})$ and the mixture incubated for 10 minutes with constant stirring. Uptake was terminated by adding $2 \mathrm{ml}$ ice cold $4 \%(\mathrm{wt} / \mathrm{vol})$ formaldehyde solution. Tubes were centrifuged at $10000 \mathrm{rpm}$ at $0^{\circ} \mathrm{C}$ for 15 minutes to separate the platelets from plasma. The supernatant was decanted and the inner side of the centrifuge tube wiped with filter paper. The pellet was digested in $0.2 \mathrm{ml}$ formic acid $(21 \mathrm{~mol} / \mathrm{l})$ and $0.3 \mathrm{ml}$ distilled water for one hour at room temperature and transferred to counting phials containing $10 \mathrm{ml}$ scintillant. Radioactivity was measured in an automatic Packard scintillation counter having 33\% efficiency for tritium. Values depicted in the tables were obtained after myocardial infarction). There was no significant difference in counts among the groups and counts were not altered by sulphinpyrazone.

Of the 11 patients with chronic stable angina, six were allocated to receive sulphinpyrazone and five to receive placebo. Of the 14 patients in the myocardial infarction group, seven were given sulphinpyrazone and seven placebo. Serotonin uptake was significantly higher in both groups of patients compared with controls (table II).

In neither group of patients was the raised serotonin uptake altered significantly by placebo (table III). By contrast, those given sulphinpyrazone showed pronounced falls in uptake (table III; fig 1). Fall in uptake increased

TABLE III-Effect of sulphinpyrazone and placebo on platelet serotonin uptake in ischaemic heart disease. Values are means (SE in parentheses)

\begin{tabular}{|c|c|c|c|c|c|}
\hline \multirow[b]{2}{*}{ Group } & \multirow[b]{2}{*}{ No } & \multirow[b]{2}{*}{ Treatment } & \multicolumn{3}{|c|}{ Platelet serotonin uptake $\left(\mathrm{cpm} / 10^{8}\right.$ platelets $)$} \\
\hline & & & Initial & 12 Weeks & 24 Weeks \\
\hline \multirow[b]{2}{*}{ Angina } & 5 & Placebo & $84.37(13.95)$ & $80 \cdot 07(15 \cdot 90)$ & $83.95(16.90)$ \\
\hline & 6 & Sulphinpyrazone & $94 \cdot 25(8 \cdot 65)$ & $\begin{array}{c}{[5 \cdot 09] \dagger} \\
70 \cdot 48(5.05)^{\star} \\
{[25 \cdot 2]}\end{array}$ & $\begin{array}{c}{[0 \cdot 49]} \\
57 \cdot 86(5 \cdot 37)^{\star \star} \\
{[38 \cdot 6]}\end{array}$ \\
\hline \multirow{2}{*}{ Myocardial infarction } & 7 & Placebo & $145 \cdot 60(17 \cdot 16)$ & $139.01(15.45)$ & $\begin{array}{c}136 \cdot 54(15 \cdot 79) \\
{[6 \cdot 22]}\end{array}$ \\
\hline & $\{7$ & Sulphinpyrazone & $137 \cdot 45(16 \cdot 26)$ & $\begin{array}{c}89 \cdot 30(12.05)^{\star} \\
{[35 \cdot 03]}\end{array}$ & $\begin{array}{c}68 \cdot 08(8 \cdot 38)^{\star \star} \\
{[50 \cdot 46]}\end{array}$ \\
\hline
\end{tabular}

Compared with initial value: ${ }^{\star} p<0.01 ;{ }^{\star \star} p<0.001$

†Figures in square brackets are percentage reductions from initial values.

TABLE IV-Effect of sulphinpyrazone and placebo on basal platelet serotonin concentrations in ischaemic heart disease. Values are means ( $S E$ in parentheses)

\begin{tabular}{|c|c|c|c|c|c|c|}
\hline \multirow[b]{3}{*}{ Group } & \multicolumn{6}{|c|}{ Basal platelet serotonin concentration ( $\mathrm{ng} / 10^{8}$ platelets) } \\
\hline & \multicolumn{3}{|c|}{ Sulphinpyrazone group } & \multicolumn{3}{|c|}{ Placebo group } \\
\hline & No & Initial & After 24 weeks & No & Initial & After 24 weeks \\
\hline Controls & 10 & $24 \cdot 51(4 \cdot 72)$ & - & 10 & $24 \cdot 51(4 \cdot 72)$ & - \\
\hline Angina & 6 & $50 \cdot 97(3 \cdot 34)$ & $\begin{array}{c}36 \cdot 80(7 \cdot 13)^{\star} \\
{[27 \cdot 8] t}\end{array}$ & 5 & $51 \cdot 85(4 \cdot 62)$ & $\begin{array}{c}49 \cdot 84(7 \cdot 59) \\
{[3 \cdot 8]}\end{array}$ \\
\hline Myocardial infarction & 6 & $70 \cdot 10(7 \cdot 82)$ & $\begin{array}{c}48 \cdot 46(6 \cdot 20)^{\star} \\
{[38 \cdot 7]}\end{array}$ & 5 & $75 \cdot 43(5 \cdot 72)$ & $\begin{array}{c}71 \cdot 33(2 \cdot 04) \\
{[5 \cdot 4]}\end{array}$ \\
\hline
\end{tabular}

Compared with initial value: ${ }^{\star} \mathrm{p}<0 \cdot 01$.

tFigures in square brackets are percentage reductions from initial values.

subtracting the blank group counts. Samples of platelet rich plasma from patients and controls were analysed simultaneously under similar conditions.

Estimation of basal platelet serotonin concentration-Basal serotonin concentration was determined using $1.0 \mathrm{ml}$ platelet rich plasma. Samples were spun at roughly $10000 \mathrm{rpm}$ for 10 minutes at $0^{\circ} \mathrm{C}$ and the supernatant carefully decanted. The platelet pellet was resuspended in $1 \mathrm{ml}$ physiological saline and used for the determination of serotonin. Platelet suspension $(1 \mathrm{ml})$ was placed in a glass stoppered tube containing borate buffer $(0.5 \mathrm{ml}, 0.5$ $\mathrm{mol} / \mathrm{l}, \mathrm{pH} 10 \cdot 0)$. pH was adjusted to between 9.5 and 10.0 and sodium chloride $(1.0 \mathrm{~g})$ and $n$-butanol $(10 \mathrm{ml})$ added. Tubes were shaken for 10 minutes and then centrifuged at $3000 \mathrm{rpm}$ for 10 minutes. The butanol layer was aspirated out and $8 \mathrm{ml}$ transferred into another glass stoppered tube containing $n$-heptane $(10 \mathrm{ml})$ and phosphate buffer $(2 \mathrm{ml}, 0.05 \mathrm{~mol} / \mathrm{l}, \mathrm{pH}$ $7 \cdot 0$ ). The tubes were shaken by rapid inversion for 10 minutes. A $1 \cdot 2 \mathrm{ml}$ sample of the aqueous phase was taken out and assayed for serotonin using the spectrofluorophotometric method of Snyder et al..$^{14}$ Solution of the appropriate concentration of serotonin (standard) and blanks (reagent) were run throughout. Recovery of serotonin by this method was $60 \%$.

Drugs and chemicals-Tritiated serotonin binoxalate solutions (specific activity $0.98 \mathrm{TBq}(26.4 \mathrm{Ci}) / \mathrm{mmol}$; New England Nuclear Corporation) were made up in physiological saline stored in the cold and dark. Trisodium citrate was used for the preparation of citrate buffer $(129 \mathrm{mmol} / \mathrm{l})$. The composition of scintillant was naphthalene $21 \mathrm{~g}$; (1-4-bis-2-5-phenyloxazolyl)benzene (POPOP) 0.024 g; 2,5-diphenyloxozole (PPO) $1.3 \mathrm{~g}$; toluene 100 $\mathrm{ml}$; methanol $60 \mathrm{ml}$; and dioxane $100 \mathrm{ml}$. Borate buffer $(0.5 \mathrm{~mol} / \mathrm{l}, \mathrm{pH} \mathrm{10.0})$ was made by dissolving $6.183 \mathrm{~g}$ boric acid in $200 \mathrm{ml}$ double distilled water, $\mathrm{pH}$ being adjusted with sodium hydroxide $(10 \mathrm{nmol} / \mathrm{l})$, saturated with salt.

\section{Results}

Table I shows the mean platelet counts recorded from the three study groups (controls, patients with chronic angina, and patients with a history of

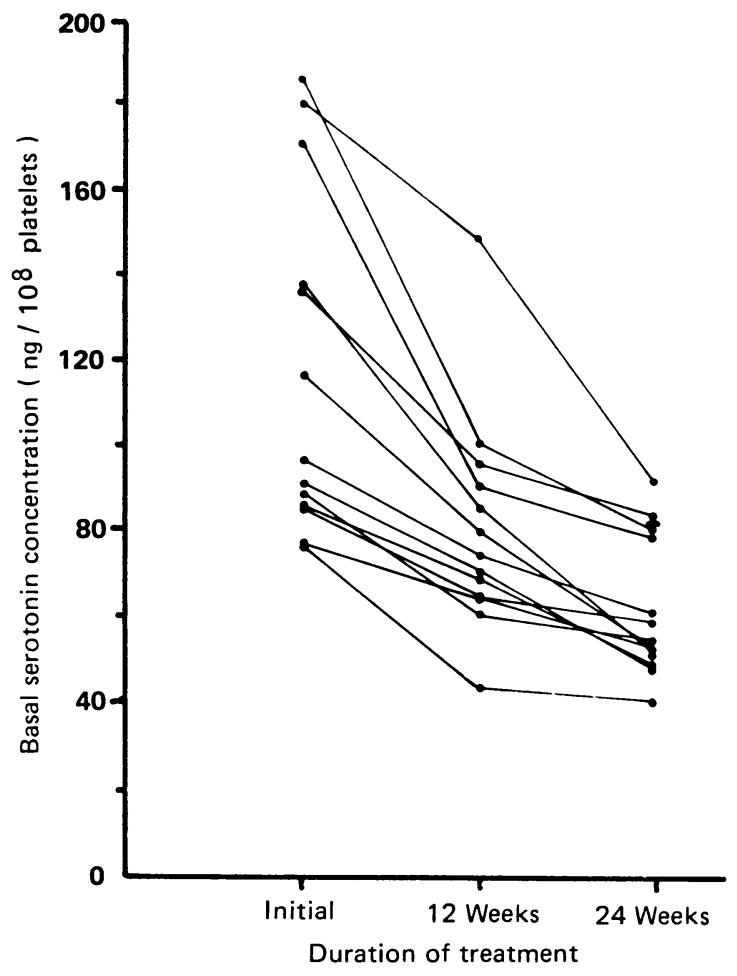

FIG 1-Individual falls in uptake of serotonin by platelets in patients treated with sulphinpyrazone. 
with the duration of treatment. With angina pectoris the mean uptake fell from $94 \cdot 25$ (SE 8.65$)$ to $70 \cdot 48(5.05) \mathrm{cpm} / 10^{8}$ platelets $(25 \cdot 2 \%$ decrease) after 12 weeks of treatment and to $57 \cdot 86(5 \cdot 37) \mathrm{cpm} / 10^{8}$ platelets (38.6\% decrease) after 24 weeks. In the myocardial infarction group serotonin uptake fell from $137 \cdot 45$ (SE 16.26) to $89 \cdot 30(12.05) \mathrm{cpm} / 10^{8}$ platelets $(35.03 \%$ decrease) after 12 weeks and to $68.08(8 \cdot 38) \mathrm{cpm} / 10^{8}$ platelets $(50 \cdot 46 \%$ decrease $)$ after 24 weeks (table III).

Basal platelet serotonin concentrations were also substantially higher in the two groups of patients compared with controls and fell significantly after 24 weeks of sulphinpyrazone (table IV; fig 2). In the group with angina the concentration fell close to the control value. Placebo had no effect on basal platelet serotonin concentration in either group of patients.
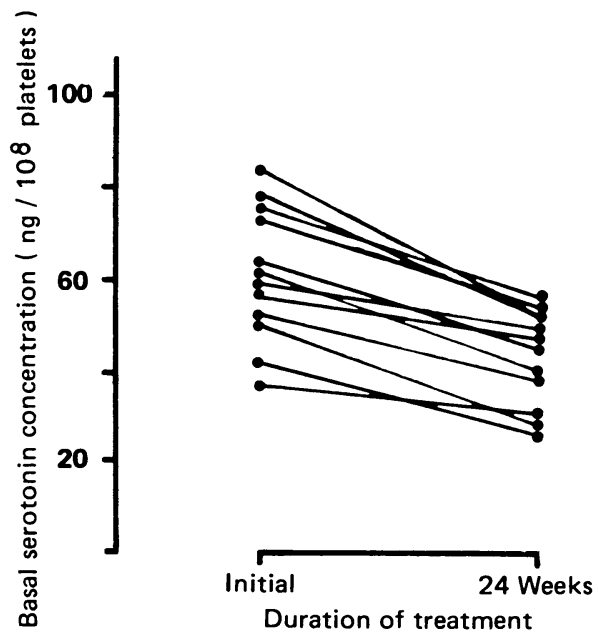

FIG 2-Individual falls in basal platelet serotonin concentrations in patients treated with sulphinpyrazone.

\section{Discussion}

The Anturane Reinfarction Trial Research Group found a reduction in sudden deaths after 24 months of treatment with sulphinpyrazone. ${ }^{12}$ The precise mechanism of the beneficial effect of the drug, however, is still not known. Endothelial damage, adhesion to subendothelium, aggregation, formation of plaques, and local release of vasoactive substances from platelets leading to spasm of coronary arteries ${ }^{15-20}$ superadded with embolic phenomenon $^{21}$ are considered to be the sequence of events in the various stages of ischaemic heart disease. Interestingly, sulphinpyrazone has been shown to inhibit several platelet functions-namely, adhesion to subendothelial cells, prostaglandin synthesis, and release of serotonin. ${ }^{62}$ Inhibition of aggregation and the release reaction appear to be important in the beneficial effects of sulphinpyrazone. We have reported finding yet another mechanism (serotoninergic) that is altered in ischaemic heart disease. Serotonin uptake by platelets was increased in patients with ischaemic heart disease, ${ }^{10}$ and this observation led us to study the effect of sulphinpyrazone on uptake and basal concentrations of serotonin in platelets in patients with chronic stable angina of effort and angina after myocardial infarction.

Serotonin is an important biogenic amine widely distributed in the body and is of considerable importance in ischaemic heart disease for three main reasons: it is stored in large amounts in platelets ${ }^{4}$; platelets possess active uptake and efflux processes to control concentrations of the amine ${ }^{9}$; and it induces aggregation both in vitro and in vivo. ${ }^{23}$ Active uptake of serotonin by platelets appears to be the most important step and probably explains the major portion of the pathological alteration in platelet function.

We found that serotonin uptake was significantly increased $(\mathrm{p}<0.01)$ both in patients with stable angina and in those with a history of myocardial infarction. These observations confirm our earlier work. ${ }^{10}$ Furthermore, significantly higher basal concentrations of serotonin were found in these patients compared with controls.

Sulphinpyrazone significantly reduced $(p<0.01)$ uptake and the raised basal concentrations of serotonin in both groups of patients. Inhibition of serotonin uptake increased with the duration of treatment. Placebo, however, failed to have any significant effect on serotonin uptake. These results clearly show a tendency of sulphinpyrazone to return serotonin uptake towards normal, and it may be that the drug exerts its antiplatelet effect through this serotoninergic mechanism.

We thank the Chemical, Industrial, and Pharmaceuticals Laboratory Ltd, the Indian Council of Medical Research, and Suhrid Geigy Pharmaceuticals for support.

\section{References}

Anturane Reinfarction Trial Research Group. Sulfinpyrazone in the prevention of cardiac death after myocardial infarction. The Anturane Reinfarction Trial. N Engl f Med 1978;298:289-95. after myocardial infarction. The Anturane Reinfarction Trial. N Engl f Med 1978;298:289-95.
Anturane Reinfarction Trial Research Group. Sulfinpyrazone in the prevention of sudden death after myocardial infarction. $N$ Engl f Med 1980;302:250-6.

3 Fuster V, Chesebro JH. Platelet thrombosis and the role of platelet inhibitor drugs. In: Kwaan HC, Dowie EJ, eds. Thrombosis. Philadelphia, London: W B Saunders Co, 1982:275-307.

4 Renaud S. Diet, drugs and thrombosis. In: Platelets, drugs and thrombosis. Hamilton symposium, 1972. Basle: Karger, 1975:182-90.

5 Gerrard JM, White JG. The influence of prostaglandin endoperoxides on platelet ultrastructure. Am f Pathol 1975;80:189-202.

6 Ali M, McDonald JWD. Effects of sulfinpyrazone on platelet prostaglandin synthesis and platelet release reaction. F Lab Clin Med 1977;89:868-75.

7 Steele P, Pattock D, Genton E. Effect of clofibrate and sulfinpyrazone on platelet survival time in coronary artery disease. Circulation 1975;52:473-6.

8 Latour JG, Theroux P, Bourassa MG. Sulfinpyrazone decreases epinephrine induced platelet aggregation after myocardial infarction. Am f Cardiol 1982;50:938-44.

9 Sneedon JM. Platelet as a model for monoamine containing neurone. Prog Neurobiol 1973;1: 151-98.

10 Puri VK, Sharma A, Mehrotra A, et al. Role of platelet serotonin in ischaemic heart disease. Indian Heart f 1983;35:162.

11 Hurst JW. Heart, arteries and veins. New York: McGraw Hill Book Co, 1982:1112-3.

12 Chung EK. Exercise electrocardiography: practical approach. Baltimore: Williams and Wilkins Co, 1978:111-2.

13 Born GVR, Gilson RB. Studies on uptake of 5-hydroxytryptamine by blood platelets. 7 Physiol (Lond) 1959;46:472-91.

14 Snyder SH, Axelrol J, Zweig N. A sensitive and specific fluorescence assay for tissue serotonin Biochem Pharmacol 1965;14:831-5.

15 Chandler AB. Mechanism and frequency of thrombosis in the coronary circulation. Thromb Res $1974 ; 4$ (suppl): $3-23$.

16 Prinzmetal M, Kennamer R, Merliss R, Wada T, Bon N. Angina pectoris. I: a variant form of angina pectoris. Preliminary report. Am F Med 1959;27:375-88.

17 Maseri AL, Annate A, Baroldi G, et al. Coronary vasospasm as a possible cause of myocardial infarction. A conclusion derived from the study of pre-infarction angina. $N$ Engl $\mathcal{F}$ Med 1978;299:1271-7.

18 Oliva PS, Breekinridge JC. Arteriographic evidence of coronary arterial spasm in acute myocardial infarction. Circulation 1977;56:366-74

19 Yamazaki H, Takahashi T, Sano T. Hyperaggregability of platelets in thrombo-embolic disorders. Thrombosis et Diathesis Haemorrhagica 1975;34:94-105.

20 Mehta J, Mehta P, Pepine CJ. Platelet aggregation in aortic and coronary venous blood in patients with and without coronary disease, 3 . Role of tachycardia, stress and propranolol. Circulation 1978:58:881-6.

21 Haerem JW. Platelet aggregation in intro-myocardial vessels of patients dying suddenly and unexpectedly of coronary artery disease. Atherosclerosis 1972;15:199-213

22 Packhom MA, Warrior ES, Glynn MP, Senyl AS, Mastard JF. Alteration of the response of platelets to surface stimuli by pyrazole derivatives. $\mathcal{f}$ Exp Med 1967;126:171-88.

23 O'Brien JR. A comparison of platelet aggregation produced by seven compounds and a comparison of their inhibitors. $\mathcal{F}$ Clin Pathol 1964;17:275.

(Accepled 27 May 1986) 